\title{
Sedimentary fractions of phosphorus before and after drainage of an urban water body (Maltański Reservoir, Poland)
}

\author{
Piotr Rzymski ${ }^{1}$, Tadeusz Sobczyński², Piotr Klimaszyk³, Przemysław Niedzielski ${ }^{2}$ \\ ${ }^{1}$ Department of Environmental Medicine, Poznan University of Medical Sciences, Rokietnicka 8, 60-806 Poznań, Poland; \\ e-mail: rzymskipiotr@ump.edu.pl (corresponding author) \\ ${ }^{2}$ Department of Analytical Chemistry, Faculty of Chemistry, Adam Mickiewicz University, Umultowska 89, 61-614 Poznań, Poland \\ ${ }^{3}$ Department of Water Protection, Faculty of Biology, Adam Mickiewicz University, Umultowska 89, 61-614 Poznań, Poland
}

\begin{abstract}
Urban reservoirs can receive high loads of chemicals, including persistent contaminants and eutrophication-promoting nutrients. To maintain their economic and recreational use, implementation of various restoration methods is often required. The Maltański Reservoir (Poland, Europe), a small, shallow and dammed urban water body, undergoes complete draining every four years as part of its restoration procedure. Here, we investigated the phosphorus $(\mathrm{P})$ content and its fractions just before the reservoir was drained and after it had been completely filled with water again. As demonstrated, the highest accumulation of $\mathrm{P}$ occurred at sites through which the main water flow is directed. Calcium-bound and residual P constituted the largest proportion of P fractions. A shift in P fractions after the reservoir was drained and sediments were left without water for at least 4 months was observed. A decrease in phytoplanktonutilized $\mathrm{NH}_{4} \mathrm{Cl}-\mathrm{P}$, Fe-P and $\mathrm{NaOH}-\mathrm{P}$ fractions was found and followed a simultaneous increase in nearly biologically inaccessible HCl-P and practically biologically inactive residual P fractions. Our study demonstrates that complete drainage of the Maltański Reservoir may additionally decrease the risk of internal P loading through shifts in its fractions.
\end{abstract}

Keywords: sediments; phosphorus fractions; drainage, municipal reservoirs

\section{Introduction}

Municipal reservoirs represent an important element in urban architecture and can be used for a variety of purposes, including recreation, sports and as a drinking-water supply. Their location, however, increases the risk of receiving effluents of potentially hazardous and persistent contaminants such as oil derivates, toxic metals and polycyclic aromatic hydrocarbons, leading to contamination of municipal surface waters (Choe et al. 2002; Azizuddin et al. 2014; Rzymski et al. 2013; Rzymski et al. 2014). Moreover, large loads of nutrients promote primary production, increase the incidence of harmful algae blooms and generally lead to a decrease in water quality, limitation of human use and in some cases, a potential health threat (O’Neil et al. 2012; Rzymski and Poniedziałek 2013). Deterioration of water quality in artificial reservoirs can occur within a relatively short period of time due to their usually small surface area and shallow character. Therefore, improper management in their catchment area can lead to rapid chemical and biological changes and, consequently, create a need to implement restoration processes to maintain their use (Cooke et al. 2005).

Along with nitrogen $(\mathrm{N})$, phosphorus $(\mathrm{P})$ is one of the most important factors responsible for limiting primary production in water bodies (Søndergaard et al. 2001). In general, aerobic conditions promote its sorption and accumulation in sediments while under anoxia, the release of $\mathrm{P}$ back to the water column is favoured. Humic acids and clay minerals containing $\mathrm{Fe}$ and $\mathrm{Al}$ oxides at their surface can absorb $\mathrm{P}$ efficiently, while silicates and carbonates, especially in the form of larger particles, play an insignificant role in P sorption. It is also known that sedimentary cycling of $\mathrm{P}$ depends mainly on the Fe status. In freshwater, Fe(III) oxides are the main compounds that bind $\mathrm{P}$ but this capacity also depends on the degree of crystallinity, availability of surface area, particle size and reactivity. For example, poorly crystallized compounds of $\mathrm{Fe}$ (III) such as ferric (III) hydroxide or lepidocrocite can absorb $\mathrm{P}$ at an approximately 20 -fold higher rate 
than goethite or hematite (Lijklema 1980; Lucotte and D'Anglejan 1988; McLaughlin et al. 1981). The sorption efficiency of $\mathrm{P}$ depends, however, on several other co-occurring factors such as microbial activity, $\mathrm{pH}$, water temperature, sediment grain size and sedimentary composition (Zhou et al. 2005; Huang et al. 2011).

High loading of $\mathrm{P}$ has been linked with increased phytoplankton biomass, turbid water and loss of biodiversity, disappearance of submerged macrophytes, fish stock changes, and decreasing top-down control by zooplankton on phytoplankton (Jeppesen et al. 2000; Søndergaard et al. 2003; Klimaszyk et al. 2014). In recent decades a great effort has been made in many parts of the world to decrease $\mathrm{P}$ effluents from catchment areas (Lewis et al. 2005; Bryhn 2009; Conley et al. 2009). Some of the most notable approaches have included a significant decrease in the use of fertilizers in agriculture, improvement of sanitation and sewage management as well as implementation of various pieces of environmental legislation. Despite a reduction in external loading, a significant part of the P pool can be driven by internal loading (Søndergaard et al. 2003). If $\mathrm{P}$ has been largely accumulated in sediments over time, its release can be persistent and intense to such an extent that no improvement of water quality can be found within a considerable amount of time (Granéli 1999; Scharf 1999; Moss et al. 2005). Such a phenomenon has been particularly observed in shallow reservoirs, in which sediments can also release $\mathrm{P}$ to the oxic water column of the lake (Boström et al., 1982; Jensen and Andersen 1992). The internal loading and bioavailability of the $\mathrm{P}$ pool accumulated in sediments does not depend exclusively on its concentrations but also on its fractions. Therefore, the extraction of particular $\mathrm{P}$ fractions rather than total $\mathrm{P}$ content enables an evaluation of the risks to lake systems (Golterman 2001; Ribeiro et al. 2008).

The following study was conducted at the Maltański Reservoir (Poland, Europe), a shallow urban water body used for recreational and sports purposes, which undergoes a complete drainage every four years as a part of its restoration programme. The reservoir was drained at the beginning of November 2012 and systematically filled with water again at the beginning of March, 2013. We aimed to investigate whether this procedure had any effect on the $\mathrm{P}$ pool in sediments and the shift in its bioavailability. We demonstrate here that periodical drainage of relatively small reservoirs located within the course of a river may affect $\mathrm{P}$ cycling and potentially decrease internal P loading.

\section{Material and Methods}

\section{Study site}

The study was conducted on the Maltański Reservoir, located in mid-western Poland, Europe $\left(52^{\circ} 24^{\prime} \mathrm{N}, 16^{\circ} 58^{\prime} \mathrm{E}\right)$ near the centre of the City of Poznań. The reservoir was built in 1952 by damming the River Cybina (right tributary of the River Warta). Currently used for sport (canoeing and rowing competitions) and recreational purposes (bathing areas), it is considered to be one of the most attractive regatta courses in Europe. It is a shallow (mean depth of $3.1 \mathrm{~m}$, maximum depth of $5.0 \mathrm{~m}$ ) and small (surface area 64 ha) water body with an approximate volume of $2.1 \mathrm{hm}^{3}$ (Gramowska et al. 2010).

Due to the morphometric features of the basin and westerly winds, the main water flow is directed near the northern shore. The eastern part of the reservoir is surrounded by forests, the southern by various sports, recreation, and shopping facilities as well as residential areas. The northern part is mainly surrounded by shrubs, an alcohol distillery, and sports facilities. Roads with high traffic intensity are situated to the west and south of the reservoir.

The whole water column of the Maltański Reservoir is well mixed by westerly winds, which prevail in this region (Joniak et al. 2000). In the eastern part of the reservoir, the River Cybina flows into the lake. Before flowing into the Maltański Reservoir, it flows through Lake Swarzędzkie (surface $93.7 \mathrm{ha}$ ) and four other small man-made reservoirs - Antoninek, Młyński, Browarny, and Olszak (Kowalczewska-Madura 2003; Gramowska et al. 2010). Raw municipal and industrial sewage was discharged into Lake Swarzędzkie over the years and it was not until 2002 that storm water was collected). As a result, high levels of organic matter accumulated in sediments and serve as a source of internal release of nutrients under anoxia conditions observed every summer (Kowalczewska-Madura 2003. The accumulation rates of organic matter in the reservoirs located between Lake Swarzędzkie and the Maltański Reservoir are relatively low due to their small surfaces $(7.2,9.2,7.1$, and 3.3 ha, respectively), duration of water residence times (mean $0.5,1.7,1.4$, and 0.6 days, respectively) and maximum depths $(0.8,2.3,2.2$, and $1.8 \mathrm{~m}$, respectively) (Gramowska et al. 2010). It all eventually results in the eutrophic character of the Maltański Reservoir. The $\mathrm{pH}$ of the water is generally alkaline and exceeds 8.0 (Rybak et al. 2012). 
Drainage of the Maltański Reservoir, supervised by the city council, is carried out every 4 years and is preceded by harvesting of fish and partial removal of emerged plants dominated by Phragmites australis. It is conducted in order to service the hydraulic structures and maintain the reservoir banks. The reservoir was completely drained at the beginning of November 2012. The sediments were left completely without water for at least 4 months until March 2013, when filling work began. The sediments were not removed during this period. The mean air temperature during this period was $2.2^{\circ} \mathrm{C}$; in November $2012: 6.2^{\circ} \mathrm{C}$; in December 2012 : $-1.9^{\circ} \mathrm{C}$; in January $2013: 1.6^{\circ} \mathrm{C}$; and in February $2013: 2.9^{\circ} \mathrm{C}$ (data taken from the nearest meteorological station).

\section{Sample collection}

Samples of bottom sediments were collected in parallel from seven sites (Fig. 1). Due to diversification of human pressure within the direct catchment area of the Maltański Reservoir, three sites were situated in the southern part of the reservoir (MR1-MR3), three in the northern part (MR4-MR6), and one in the western part (MR7). Samples were not collected from the eastern part of the reservoir due to the concrete bottom. The samples were collected at the beginning of November 2012 right before the drainage of the reservoir was launched and in June 2013 when the reservoir had been completely filled with water.

A plastic tube sampler (diameter of $5 \mathrm{~cm}$ and length of $1 \mathrm{~m}$ ) was used to collect sediments. Because $\mathrm{P}$ can be released only from a limited sediment depth
(Søndergaard et al. 2003), the surface layer, approximately $10-\mathrm{cm}$ thick, was collected for further analysis. Three replicates from each sampling site were collected. The sediments were placed in plastic containers and transported to the laboratory in cold storage.

\section{Sediment analyses}

The degree of sample hydration was determined directly after their collection. Organic matter content was estimated as the loss of ignition at $550^{\circ} \mathrm{C}$ and calculated as the difference between total and remaining inorganic matter content. Moreover, ignited samples were extracted with $\mathrm{HCl}$ and the non-extractable part was gravimetrically determined as silica (Håkanson and Jansson 1983). The fractionation of $\mathrm{P}$ was performed by sequential extraction according to the Psenner (1988) procedure. The following fractions were extracted:

1) $\mathrm{NH}_{4} \mathrm{Cl}-\mathrm{P}$ - loosely bound and extractable with $\mathrm{NH}$ ${ }_{4} \mathrm{Cl}$ solution;

2) Fe-P - bound with iron, extractable with sodium hydrocarbonate and sodium thiosulphate solution;

3) $\mathrm{NaOH}-\mathrm{P}$ - bound with $\mathrm{Al}$ and organic matter and extractable with $\mathrm{NaOH}$ solution;

4) HCl-P - bound with calcium carbonate and extractable with $\mathrm{HCl}$ solution;

5) Res.-P - residual, permanently bound with the matrix after complete mineralization.

Biologically active $\mathrm{P}$ (BAP) was defined as the sum of $\mathrm{NH}_{4} \mathrm{Cl}-\mathrm{P}, \mathrm{Fe}-\mathrm{P}$ and $\mathrm{NaOH}-\mathrm{P}$ while non-biologically active $\mathrm{P}$ (NBAP) was defined as the sum of HCl-P and Res.-P.

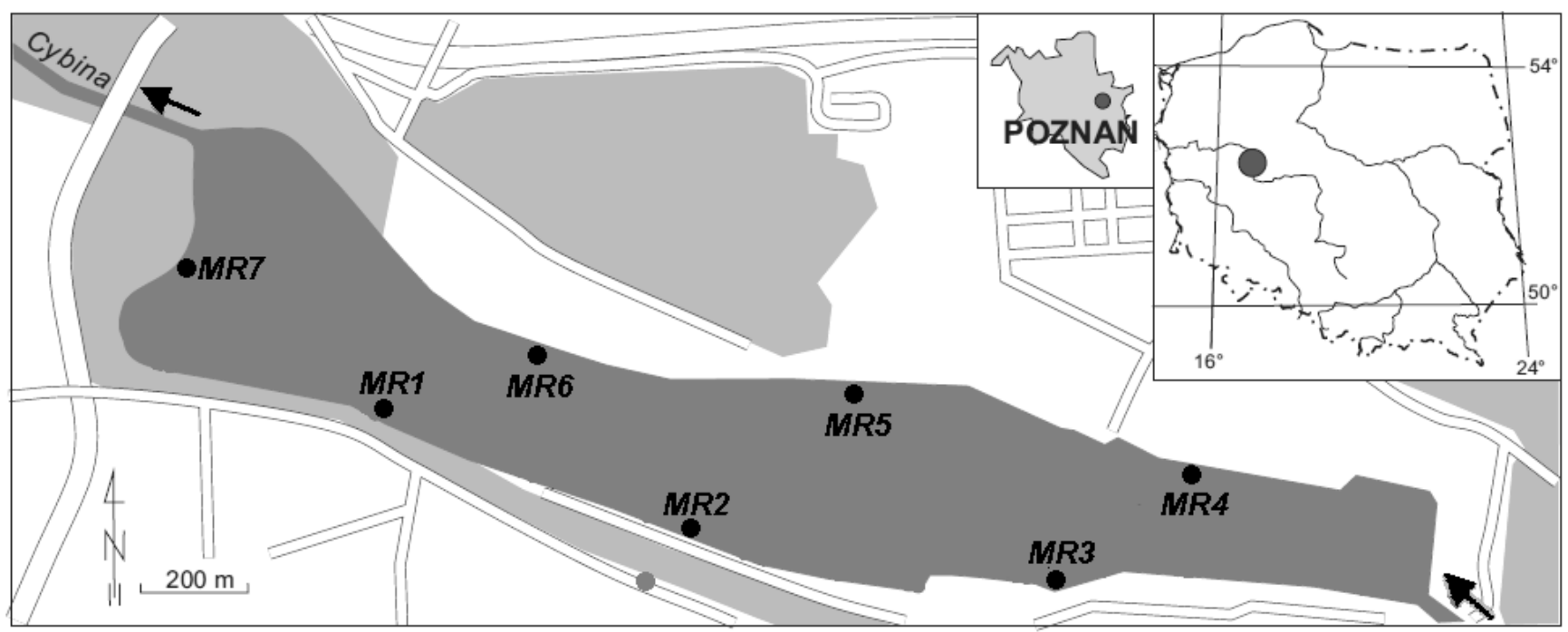

Fig. 1. Map of the Maltański Reservoir and relative location of sampling sites 


\section{Statistical analyses}

The results were analysed using STATISTICA 10.0 software (StatSoft, U.S.A.). Gaussian distribution was tested with Shapiro-Wilk's test, and because most of the data did not meet this assumption, non-parametric methods were employed. To evaluate differences in sediment chemistry before and after drainage, Wilcoxon's matched pairs test was used. $P$ value $<0.05$ was considered as statistically significant.

\section{Results}

Sediments of the Maltański Reservoir were characterized by a low contribution of organic matter that did not differ statistically at any sampling site before and after drainage (Table 1).

Table 1. Content of organic matter in sediments of the Maltański Reservoir (MR1-MR7) before the complete drainage (in 2012) and after filling again with water (2013)

\begin{tabular}{ccc}
\hline \multirow{2}{*}{ Site } & \multicolumn{2}{c}{ Organic matter [\%] } \\
\cline { 2 - 3 } & Before drainage & After drainage \\
\hline MR1 & 0.9 & 0.9 \\
\hline MR2 & 1.4 & 3.2 \\
\hline MR3 & 1.7 & 0.4 \\
\hline MR4 & 2.3 & 1.6 \\
\hline MR5 & 1.5 & 1.5 \\
\hline MR6 & 3 & 0.8 \\
\hline MR7 & 3.9 & 2.2 \\
\hline Mean $( \pm S D)$ & $2.1( \pm 1.0)$ & $1.5( \pm 1.0)$
\end{tabular}

Relatively low P content was found in collected sediments (Fig. 2A). The mean concentration observed after drainage was $216.4 \mathrm{mg} \mathrm{kg}^{-1}$ while after refilling it

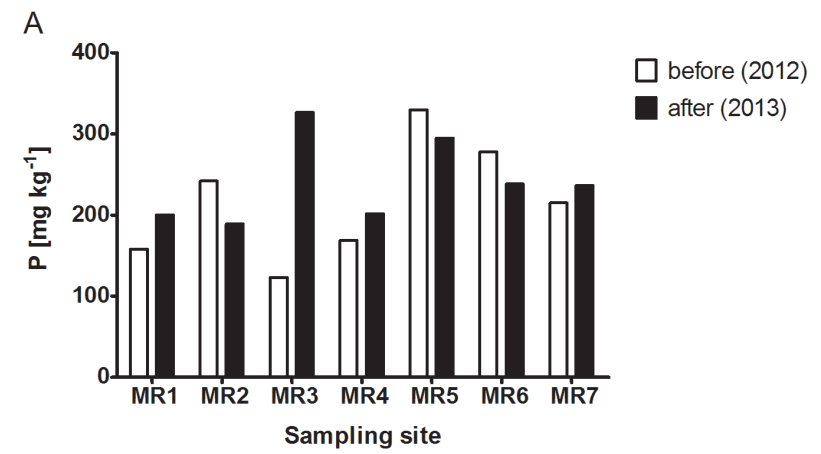

reached $240.9 \mathrm{mg} \mathrm{kg}^{-1}$ ( $\left.\mathrm{p}>0.05\right)$. In both investigated periods, the highest level of $\mathrm{P}$ was found in sediments collected at northern sites (MR5-MR6).

Among the five extracted $\mathrm{P}$ fractions, $\mathrm{HCl}-\mathrm{P}$ was the most abundant while $\mathrm{NH}_{4} \mathrm{Cl}-\mathrm{P}$ constituted the lowest share (Fig. 2B). There was a significant shift in $\mathrm{P}$ fractions after the reservoir was drained and sediments were left without water for at least 4 months. A decrease in bioavailable $\mathrm{NH}_{4} \mathrm{Cl}-\mathrm{P}, \mathrm{Fe}-\mathrm{P}$ and $\mathrm{NaOH}-\mathrm{P}$ was observed at every studied site (Fig. 3). Before drainage these fractions constituted on average $48.1 \%$ of the total sedimentary P pool, whereas after the drainage their contribution decreased to $33.2 \%$. The greatest decrease (by a mean of $8.6 \%$ ) was observed for $\mathrm{NaOH}-\mathrm{P}$, but the mean share of the other two also decreased significantly $(p<0.05)$. These changes were followed by a general increase in the less bioavailable $\mathrm{HCl}-\mathrm{P}$ fraction and practically non-biologically available Res.-P. The mean share of these two fractions increased from $51.8 \%$ before draining to $65.0 \%$ after the reservoir had been refilled with water (Fig. 2B). The general order rank of $\mathrm{P}$ fractions did not, however, differ between sampling sites before the reservoir was drained ( $\mathrm{HCl}-\mathrm{P}>\mathrm{Fe}-\mathrm{P}>$ $\mathrm{NaOH}-\mathrm{P}>$ Res. $-\mathrm{P}>\mathrm{NH}_{4} \mathrm{Cl}-\mathrm{P}$ ) and after it was filled ( $\mathrm{HCl}-\mathrm{P}>\mathrm{Fe}-\mathrm{P}>$ Res. $-\mathrm{P}>\mathrm{NaOH}-\mathrm{P}>\mathrm{NH}_{4} \mathrm{Cl}-\mathrm{P}$ ).

\section{Discussion}

Like other urban water bodies, the Maltański Reservoir is potentially subject to degradation as it can receive various chemical effluents. As a small, shallow and through-flow reservoir, the processes of organic matter accumulation can occur more rapidly compared to larger reservoirs. It was already shown that it is overloaded with nutrients inflowing with the

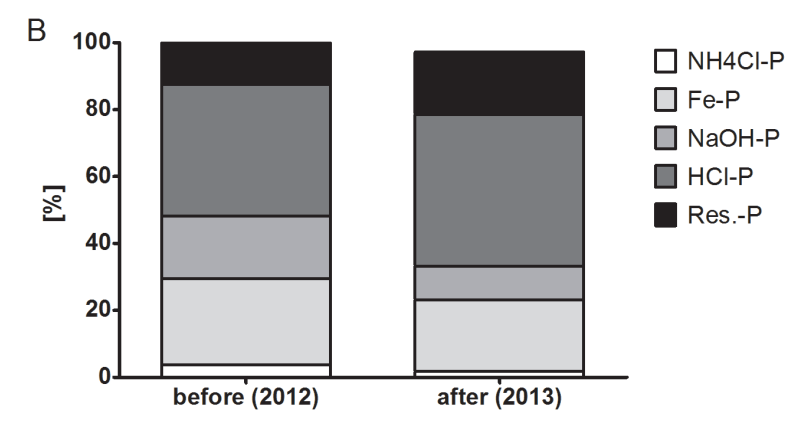

Fig. 2. The sedimentary P content (A) and the share of its fractions (B) before the complete drainage (in 2012) and after filling again with water (2013) 


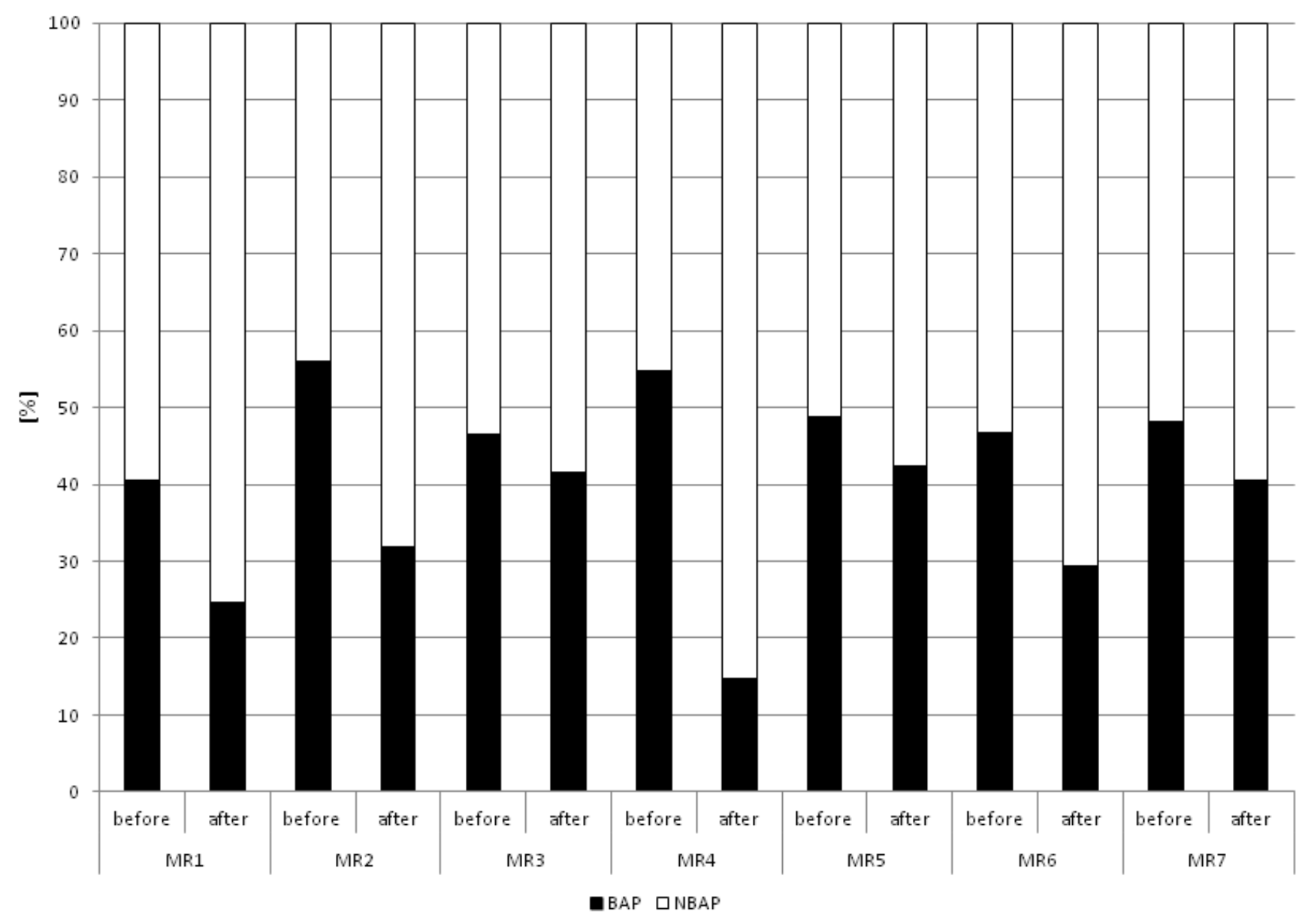

Fig. 3. The sedimentary share of biologically active P (BAP) and non-biologically active P NBAP) before the complete drainage (in 2012) and after filling again with water (2013)

River Cybina from hypertrophic Lake Swarzędzkie (Kowalczewska-Madura 2003). This is a persistent situation as over the years raw municipal and industrial sewage was discharged into Lake Swarzędzkie and it was not until 2002 that storm water was collected (Kowalczewska-Madura 2003). As a result, high levels of organic matter accumulated in sediments and serve as a source of internal release of nutrients under anoxia conditions observed every summer. Lake Swarzędzkie can be considered as one of the main sources of nutrients for the Maltański Reservoir (Kowalczewska-Madura and Gołdyn 2006). Both $\mathrm{N}$ and $\mathrm{P}$ can also be transported via surface runoff, particularly after heavy rainfall events (Klimaszyk and Rzymski 2013; Barałkiewicz et al. 2014). As the direct catchment area of the Maltański Reservoir is highly urbanized, with roads, various sports, recreation, and shopping facilities as well as residential areas, the nonpermeable surface increases washing out and trans- port of emitted chemicals. As already demonstrated, the Maltański Reservoir receives large loads of toxic metals, which are further accumulated in biota including macroalgae, macrophytes and bivalves (Rybak et al. 2013; Rzymski et al. 2013; Rzymski et al. 2014).

Despite its location and urban character, the total P content found in sediments of the Maltański Reservoir, however significant, was lower compared to other Polish lakes (Sobczyński and Joniak 2009a; Sobczyński and Joniak 2009b), or dammed and urban reservoirs (Kowalczewska-Madura et al. 2010; Smal et al. 2013). The highest concentrations were noted at the northern side of the Maltański Reservoir through which the main flow of water from the River Cybina is directed. This highlights the role of this stream in influencing the chemistry of the studied water body and stimulating primary production, which was reported to be dominated by cyanobacteria, including potentially toxic species (Kobos et al. 2013). 
To fully assess the risk of internal P loading, a sequential extraction analysis was performed. As revealed, the mean share of the two most bioavailable $\mathrm{P}$ fractions $\left(\mathrm{NH}_{4} \mathrm{Cl}-\mathrm{P}\right.$ and $\left.\mathrm{Fe}-\mathrm{P}\right)$ constituted no more than $30 \%$ before the reservoir was drained and did not exceed $25 \%$ after it was filled again with water. The contribution of the less readily bioavailable $\mathrm{NaOH}-\mathrm{P}$ fraction was also relatively low. As the Maltański Reservoir is a shallow water body with a well-mixed water column, all of these fractions $\left(\mathrm{NH}_{4} \mathrm{Cl}-\mathrm{P}, \mathrm{Fe}-\mathrm{P}\right.$ and $\left.\mathrm{NaOH}-\mathrm{P}\right)$ can be involved in $\mathrm{P}$ internal loading. As demonstrated, they can all be utilized by phytoplankton and be responsible for bloom outbreaks (Dorich et al. 1984; Fabre et al. 1996; Rydin 2000; Kaiserli et al. 2002). The HCl-P fraction, which mainly represents calcium-bound $\mathrm{P}$, was found to have the highest sedimentary contribution in the Maltański Reservoir regardless of the time the samples were collected. While this fraction contributes to the permanent storage of $\mathrm{P}$ in sediments, it appears to be non-motile, rarely released from sediments and therefore, not readily utilized by phytoplankton (Kaiserli et al. 2002; Jin et al. 2006; Ribeiro et al. 2008). Compared to various other lake sediments for which the P extraction analyses were performed, a relatively high share of Res.-P was observed in the Maltański Reservoir (Sobczyński and Joniak 2009a; Sobczyński and Joniak 2009b). This fraction includes not extractable organic phosphorus and refractory $\mathrm{P}$ compounds (and possibly a low amount of undetermined organic $\mathrm{P}$ in the extractable $\mathrm{P}$ fractions). Res-P is considered to be permanently combined with minerals and, thus, to be biologically unavailable (Hupfer et al. 1995; Rydin 2000).

The complete drainage of the Maltański Reservoir is performed every 4 years in order to sustain its sporting role. In 2012, the sediment was not removed from the littoral zone, thereby creating the possibility to fully oxidize its surface layer. This resulted in a shift in the share of $\mathrm{P}$ fractions, slightly decreasing bioavailable $\mathrm{NH}_{4} \mathrm{Cl}-\mathrm{P}, \mathrm{Fe}-\mathrm{P}$ and $\mathrm{NaOH}-\mathrm{P}$ and increasing the contribution of HCl-P and Res.-P fractions. When the reservoir was filled again with water, its sediments became a less important source of $\mathrm{P}$ for the mixed water column. It can be therefore predicted that draining of small shallow reservoirs during the autumn/winter period can additionally result in a decrease in internal $P$ loading. It cannot, however, be a sufficient method to prevent the eutrophication of the water body, particularly if the external sources (urban runoff and inflowing streams) play a significant role in loading nutrient enrichment.

\section{References}

Azizuddin A.D., Ali N.A.M., Tay K.S., Bin Abas M.R., Simoneit B.R.T., 2014, Characterization and sources of extractable organic matter from sediment cores of an urban lake (Tasik Perdana), Kuala Lumpur, Malaysia, Environ. Earth Sci. 71(10): 4363-4377.

Barałkiewicz D., Chudzińska M., Szpakowska B., Swierk D., Gołdyn R., Dondajewska R., 2014, Storm water contamination and its effect on the quality of urban surface waters, Environ. Monit. Assess. 186(10): 6789-6803.

Boström B., Jansson M., Forsberg C., 1982, Phosphorus release from lake sediments, Arch. Hydrobiol. Beih. Ergebn. Limnol. 18: 5-59.

Bryhn A.C., 2009, Sustainable phosphorus loadings from effective and cost-effective phosphorus management around the Baltic Sea, PLoS ONE 4: e5417.

Choe J.E., Bang K.W., Lee J.H., 2002, Characterization of surface runoff in urban areas, Water Sci. Technol. 45(9): 249-254.

Conley D.J., Paerl H.W., Howarth R.W., Boesch D.F., Seitzinger S.P., Havens K.E., Lancelot C., Likens G.E., 2009, Controlling eutrophication: nitrogen and phosphorus, Science 323: 1014-1015.

Cooke D.G., Welch E.B., Peterson S., Nichols S.A., 2005, Restoration and Management of Lakes and Reservoirs, Third Edition, CRC Press, Boca Raton, pp. 591.

Dorich R.A., Nelson D.W., Sommers L.E., 1984, Availability of phosphorus to algae from eroded soil fractions, Agr. Ecosyst. Environ. 11(3): 253-264.

Fabre A., Qotbi A., Dauta A., Baldy V., 1996, Relation between algal available phosphate in the sediments of the River Garonne and chemically-determined phosphate fractions, Hydrobiologia 335(1): 43-48.

Golterman H.L., 2001, Fractionation and bioavailability of phosphates in lacustrine sediments: a review, Limnetica 20(1):15-29.

Gramowska H., Krzyzaniak I., Baralkiewicz D., Goldyn R., 2010, Environmental applications of ICP-MS for simultaneous determination of trace elements and statistical data analysis, Environ. Monit. Assess. 160: 479-490.

Granéli W., 1999, Internal phosphorus loading in Lake Ringsjön, Hydrobiologia 404:19-26.

Håkanson L., Jansson M., 1983, Principles of lake sedimentology. Springer-Verlag, Berlin-Heidelberg-New YorkTokyo, pp. 316.

Huang L., Fu L., Jin C., Gielen G., Lin X., Want H., Zhang Y., 2011, Effect of temperature on phosphorus sorption to sediments from shallow eutrophic lakes, Ecol. Eng. 37(10): 1515-1522.

Hupfer M., Gachter R., Giovanoli R., 1995, Transformation of phosphorus species in settling seston and during early sediment diagenesis, Aquat. Sci. 57(4): 305-324.

Jensen H.S., Andersen F.Ø., 1992, Importance of temperature, nitrate, and $\mathrm{pH}$ for phosphate release from aerobic sediments of four shallow, eutrophic lakes, Limnol. Oceanogr. 37(3): 577-589. 
Jeppesen E., Jensen J.P., Søndergaard M., Lauridsen T., Landkildehus F., 2000, Trophic structure, species richness and biodiversity in Danish lakes: changes along a phosphorus gradient, Freshwater Biol. 45(2): 201-213.

Jin X., Wang S., Pang Y., Chang Wu F., 2006, Phosphorus fractions and the effect of $\mathrm{pH}$ on the phosphorus release of the sediments from different trophic areas in Taihu Lake, China, Environ. Pollut. 139(2): 288-295.

Kaiserli A., Voutsa D., Samara C., 2002, Phosphorus fractionation in lake sediments-Lakes Volvi and Koronia N. Greece, Chemosphere 46(8): 1147-1155.

Klimaszyk P., Piotrowicz R., Rzymski, P., 2015, Changes in the ecosystem of shallow softwater lake induced by the Great Cormorant roosting colony, J. Limnol. 74(1): 114122.

Klimaszyk P., Rzymski P., 2013, Catchment vegetation can trigger lake dystrophy through changes in runoff water quality, Annal. Limnol. - Int. J. Limnol. 49(3):191-197.

Kobos J., Błaszczyk A., Hohlfeld N., Toruńska-Sitarz A., Krakowiak A., Hebel A., Sutryk K., Grabowska M., Toporowska M., Kokociński M., Messyasz B., Rybak A., Napiórkowska-Krzebietke A., Nawrocka L., Pełechata A., Budzyńska A., Zagajewski P., Mazur-Marzec H., 2013, Cyanobacteria and cyanotoxins in Polish freshwater bodies, Oceanol. Hydrobiol. Stud. 42(4): 358-378.

Kowalczewska-Madura K., 2003, Mass balance calculations of nitrogen and phosphorus for Swarzędzkie Lake, Limnol. Rev.3: 113-118.

Kowalczewska-Madura K., Dondajewska R., Gołdyn R., 2010, Total phosphorus and organic matter content in bottom sediments of lake under restoration measures with iron treatment, Limnol. Rev. 10(3-4): 139-145.

Kowalczewska-Madura K., Gołdyn R., 2006, Anthropogenic changes in water quality in the Swarzędzkie Lake (West Poland), Limnol. Rev. 6: 147-154.

Lewis W.M., Wurtsbaugh W.A., Paerl H.W., 2011, Rationale for control of anthropogenic nitrogen and phosphorus to reduce eutrophication of inland waters, Environ. Sci. Technol. 45(24): 10300-10305.

McLaughlin J.R., Ryden J.C., Syers J.K., 1981, Sorption of inorganic phosphate by iron and aluminium containing components, J. Soil Sci. 32(3): 365-377.

Moss B., Barker T., Stephen D., Williams A. E., Balayla D., Beklioglu M., Carvalho L., 2005, Consequences of reduced nutrient loading on a lake system in a lowland catchment: deviations from the norm?, Freshwater Biol. 50912): 1687-1705.

O’Neil J.M., Davis T.W., Burford M.A., Gobler C.J., 2012, The rise of harmful cyanobacteria blooms: The potential roles of eutrophication and climate change, Harmful Algae 14: 313-334.
Psenner R., Bostrom B., Dinka M., Pettersson K., Pucsko R., Sager M., 1988, Fractionation of phosphorus in suspended matter and sediment, Arch. Hydrobiol. Beih. Ergebn. Limnol.30: 98-112.

Ribeiro, D.C., Martins, G., Nogueira, R., Cruz, J.V., Brito A.G., 2008, Phosphorus fractionation in volcanic lake sediments (Azores - Portugal), Chemosphere 70(7): 1256-1263.

Rybak A., Messyasz B., Łęska B., 2012, Freshwater Ulva (Chlorophyta) as a bioaccumulator of selected heavy metals $(\mathrm{Cd}, \mathrm{Ni}$ and $\mathrm{Pb})$ and alkaline earth metals $(\mathrm{Ca}$ and Mg), Chemosphere 89(9):1066-1076.

Rydin E., 2000, Potentially mobile phosphorus in Lake Erken sediment, Water Res. 34(7): 2037-2042.

Rzymski P., Klimaszyk P., Niedzielski P., Poniedziałek B., 2013, Metal accumulation in sediments and biota in Malta Reservoir (Poland), Limnol. Rev. 13(3): 163-169.

Rzymski P., Niedzielski P., Klimaszyk P., Poniedziałek B., 2014, Bioaccumulation of selected metals in bivalves (Unionidae) and Phragmites australis inhabiting a municipal water reservoir, Environ. Monit. Assess. 186(5): 3199-3212.

Scharf W., 1999. Restoration of the highly eutrophic lingese reservoir, Hydrobiologia 416: 85-96.

Smal H., Ligęza S., Baran S., Wójcikowska-Kapusta A., Obroślak R., 2013, Nitrogen and phosphorus in bottom sediments of two small dam reservoirs, Pol. J. Environ. Stud. 22(5): 179-189.

Sobczyński T., Joniak T., 2009, Differences in composition and proportion of phosphorus fractions in bottom sediments of Lake Góreckie (Wielkopolska National Park), Environ. Protect. Eng. 35(2): 89-95.

Sobczyński T., Joniak T., 2009, Vertical changeability of physical-chemical features of bottom sediments in three lakes, in aspect type of water mixes and intensity of human impact, Pol J. Environ. Stud. 18(6): 1093-1099.

Søndergaard M., Jensen J.P., Jeppesen E., 2001, Retention and internal loading of phosphorus in shallow, eutrophic lakes, ScientificWorldJournal $23: 427-442$.

Søndergaard M., Jensen J.P., Jeppesen E., 2003, Role of sediment and internal loading of phosphorus in shallow lakes. Hydrobiologia 506-509(1): 135-145.

Vincent A.G., Sundqvist M.K., Wardle D.A., Giesler R., 2014, Bioavailable soil phosphorus decreases with increasing elevation in a subarctic tundra landscape, PLoS One. 9: e92942.

Zhou A., Tang H., Wang D., 2005, Phosphorus adsorption on natural sediments: modeling and effects of $\mathrm{pH}$ and sediment composition, Water Res. 39(7): 1245-1254. 